\title{
Bodies of Knowledge: The Nineteenth-Century Anatomical Atlas in the Spaces of Art and Science
}

\section{Cindy Stelmackowich}

Volume 33, numéro 1-2, 2008

Medical Tabulae: Visual Arts and Medical Representation Tabulae médicale : arts visuels et représentation médicale

URI : https://id.erudit.org/iderudit/1069549ar

DOI : https://doi.org/10.7202/1069549ar

Aller au sommaire du numéro

\section{Éditeur(s)}

UAAC-AAUC (University Art Association of Canada | Association d'art des universités du Canada)

\section{ISSN}

0315-9906 (imprimé)

1918-4778 (numérique)

Découvrir la revue

Citer cet article

Stelmackowich, C. (2008). Bodies of Knowledge: The Nineteenth-Century Anatomical Atlas in the Spaces of Art and Science. RACAR : Revue d'art canadienne / Canadian Art Review, 33(1-2), 75-86.

https://doi.org/10.7202/1069549ar

\section{Résumé de l'article}

Au début du dix-neuvième siècle, la médecine de l'Europe de l'ouest a subi une transformation institutionnelle et discursive suite à de nouvelles perceptions en études anatomiques. De nouvelles tendances culturelles, politiques et hygiéniques (par exemple, la découverte de la " saleté » et les maladies qui y sont associées) ont encouragé la communauté médicale à faire du cadavre le site d'une nouvelle méthode " scientifique » de la connaissance médicale. En conséquence, il y a eu une recrudescence de publications d'atlas composés d'illustrations minutieuses fondées sur des observations détaillées de phénomènes physiologiques. Cet article s'intéresse à la façon dont les illustrations médicales du dix-neuvième siècle encodaient une nouvelle manière de voir le corps et analyse le rôle qu'elles ont joué à donner à la médecine moderne le professionnalisme qu'on lui connaît. Les atlas anatomiques du dix-neuvième siècle étaient tout à fait différents de leurs prédécesseurs : ils possédaient des dépliants " grandeur nature ", des lithographies raffinées mettant l'accent sur le type de tissus, ainsi que des mécanismes uniques pour le cadrage et le recadrage ; le tout leur prodiguait un langage précis et une grammaire visuelle. Cet article analyse la rhétorique visuelle à la fois complexe et contradictoire des atlas : leurs codes d'identification parfaits et réalistes et les écoles d'art néoclassiques que les atlas exploitaient ouvertement.
Tous droits réservés @ C UAAC-AAUC (University Art Association of Canada | Association d'art des universités du Canada), 2008
Ce document est protégé par la loi sur le droit d'auteur. L’utilisation des services d'Érudit (y compris la reproduction) est assujettie à sa politique d'utilisation que vous pouvez consulter en ligne.

https://apropos.erudit.org/fr/usagers/politique-dutilisation/ 


\title{
Bodies of Knowledge: The Nineteenth-Century Anatomical Atlas in the Spaces of Art and Science
}

\author{
Cindy Stelmackowich, Binghamton University (New York) and Carleton University (Ottawa)
}

\begin{abstract}
Résumé
Au début du dix-neuvième siècle, la médecine de l'Europe de l'ouest a subi une transformation institutionnelle et discursive suite à de nouvelles perceptions en études anatomiques. De nouvelles tendances culturelles, politiques et hygiéniques (par exemple, la découverte de la « saleté » et les maladies qui y sont associées) ont encouragé la communauté médicale à faire du cadavre le site d'une nouvelle méthode « scientifique » de la connaissance médicale. En conséquence, il y a eu une recrudescence de publications d'atlas composés d'illustrations minutieuses fondées sur des observations détaillées de phénomènes physiologiques. Cet artıcle s'intéresse à la façon dont les illustrations médıcales du dix-neuvième siècle encodaient une nouvelle manière de voir le corps et analyse le rôle qu'elles ont joué à donner à la médecine moderne le professionnalisme qu'on lui connaît. Les atlas anatomiques du dix-neuvième siècle étaient tout à fait différents de leurs prédécesseurs : ils possédaient des dépliants « grandeur nature », des lithographies raffinées mettant l'accent sur le type de tissus, ainsi que des mécanismes uniques pour le cadrage et le recadrage ; le tout leur prodiguait un langage précis et une grammaire visuelle. Cet article analyse la rhétorique visuelle à la fois complexe et contradictoire des atlas : leurs codes d'identification parfaits et réalistes et les écoles d'art néoclassiques que les atlas exploitaient ouvertement.
\end{abstract}

\begin{abstract}
A the turn of the nineteenth century in Europe, new forms of anatomical instruction and new viewing technologies contributed to the creation of a system of pathological anatomy that claimed to offer a roadmap of the human body, decipherable by surgeon and physician alike. The use of new approaches to anatomy in the training of both art and medical students resulted in new ways of seeing the body and its surfaces - ways of secing that were codified in the production of a ncw kind of profusely illustrated anatomical text: the anatomical atlas. By examining the discursive moment of scientific and representational crisis in which the anatomical atlas emerged, this essay will focus on the ways in which its nineteenth-century manifestation became a persuasive part of medicine's struggle to emerge as a professionalized and institutionalized discipline in Western Europe.

Nineteenth-century anatomical atlases were strikingly different from eighteenth-century atlases and other nineteenthcentury textbooks; their "life-sized" scale, large extendable foldouts, refined lithographic pictorial characteristics highlighting tissue types, as well as their unique framing and cropping devices, established a specific language and visual grammar. Opposed to earlier anatomical treatises that tended to specify and classify disease based on elaborate tables of nosological species, these profusely illustrated textbooks correlated clinical history with anatomical-pathological findings in order to prepare mcdical students for the experience of dissecting a cadaver. In lithographic and chromo-lithographic anatomical illustrations that were printed on oversize folio woven paper and bound together into innovative single and multi-volume formats, morbid anatomists published a lifetime of clinical and anatomical research that was ultimately to relate the dead to the living body. As a result of the growing importance placed on giving each carcfully observed dissected anatomical structure an cxact and defining visual character, the anatomical atlas became a key instrument wherein physicians would negotiate their professional status and
\end{abstract}

authority. Positive reviews of these illustrated treatises frequently secured for their authors lucrative and prestigious positions.

Situated between Western art history and the history of medicine, the nineteenth-century anatomical atlas hangs between science and art in ways that demand analysis. On the one hand, literature on anatomical illustration has tended to insert the imagery into the grand narratives of Western histories of art that stretched back more than seven hundred years. ${ }^{1}$ This literature has tended to closely relate the major developments in anatomical illustration to styles, events, and trends in art history and in medicine and surgery, resulting in a focus on period techniques and scientific inventions. The problem here is not to examine how the anatomical atlas was inserted into the grand narratives of art history, but rather to consider how the atlases put pressure on the habitual assumptions and procedures of the discipline of art history itself. On the other hand, the Western history of medicine has viewed visual images with little understanding of their representational codes or discursive conditions. Medical historians often view illustrations as evidence, without questioning the impact of visual codes on observation and representation and without examining the meanings encoded within anatomical knowledge. Although interesting histories of scientific illustration and medical imagery have been written in recent years, and although this area of enquiry has become a dynamic field, due in part to a number of large-scale museum exhibitions on medical imagery during the past decade, ${ }^{2}$ these catalogues have failed to qucstion either the status of science or how the visual codes of realism and truth became institutionalized in medical science. Accordingly, one exhibition cataloguc claims that medical imagery and artifacts represented merely a "successful merging of form and function, science and art." 3 But how and why were the languages of medical science and anatomical illustration recast during the ninetcenth century? 
Cadavers, Public Health, and the Nineteenth-Century Professional Physician

In 1824 William MacKenzie, professor of anatomy and surgery and member of the Royal College of Surgeons of London, addressed one of the medical profession's most pressing concerns: the need to secure an abundant and steady supply of dead bodies for the schools of anatomy. ${ }^{4}$ MacKenzic maintained that though ample provision of cadavers was made for the teachers of anatomy for their public demonstrations, dissections needed to be performed by students individually. MacKenzic's Appeal to the Public and to the Legislature, on the Necessity of Affording Dead Bodies to the Schools of Anatomy went on to cxplain that anatomy students' acquaintance with the human structure through dissection would not only be a benefit to "the progress of medical science," but also that it would affirm "the dignity and high responsibility of the medical profession, and ... the necessity of laying well the groundwork upon which a knowledge of medicine is to be founded." 5 Arguing that the modern-day surgeon increasingly required an objective, detailed and practical knowledge of the structure of the human body, MacKenzie stated that "practice on the living ought, from the very first, to be under the guidance of a clear and well-understood system of rules, which the surgcon has already put to the tcst, as far as it is possible, on the dead body." 6 He insisted that anatomical knowledge about the body would achieve full effectiveness only if it was supplemented by constant, rational observation, both visual and tactile:

The student must bring into view the parts of the dead body which he is studying with the very hand which is afterwards to divide and separate them in his operations on the living: he must meditate for hours and for days over the dissection he has made, displacing and replacing the different muscles, arteries and ncrves, many times over, before he can impress upon his mind an accurate idea of their structure, their situation, and their mutual connexions. ${ }^{7}$

Published at a timc when physicians in Britain still had to rely on illegal means of acquiring cadavers, before the passing of the Anatomy Act in 1832, MacKenzie's Appeal was representative of the unrelenting attempts by British physicians to endorse and regulate dissection as a necessary, useful, and professional medical activiry. ${ }^{8}$ At the end of the eighteenth century in Wcstern Europe, a major epistemological shift in medical science occurred that moved medical thought firmly in the direction of empirical clinical enquiry. Most notably there devcloped a pathological anatomy tradition in which clinical symptoms in life were correlated with anatomical lesions at the tissuc level: lesions discovered during postmortem examinations. In both medical training and practice, these new conceptions of anatomy worked to create a novel institutional cohesion between physicians and surgeons, shaping a new practice of knowledge of the body, first in France and then in England." Along with signalling the desire to institute an anatomical basis for scientific medicine, authoritative discursive appeals such as MacKenzie's became instrumental in laying out a new sct of rules for the formation and imparting of medical and anatomical knowledge based on new anatomical techniques of seeing and knowing.

As an authoritative document concerned with the politics of the dead body, MacKenzie's Appeal was produced at a time when Westcrn Europe was experiencing a daunting serics of major public health concerns. During the early ninctcenth century, medical practitioncrs, along with civic officials, were preoccupied with the devastating effects of a long series of epidemic diseases-most notoriously, fever, cholera, and influenza-that appeared in the growing industrial cities. ${ }^{10}$ These diseases were portrayed as being unlike anything then known; both their causes and their patterns were very much matters of speculation. "Anxieties became extreme as miasmatic theories of disease emerged, suggesting that noxious, invisible, and impure air, as well as soil, werc the basis of much illness. Anxious to improve and ensure the health of citizens through social reform initiatives and public health cducation, medical and civic officials in Paris and London made increased efforts to address those factors believed to be associated with the spread of infectious diseases. ${ }^{12}$ The main objective and expanded role of the early nineteenthcentury public hcalth movement thereby entailed close study of the accumulated refuse that was believed to cause the illnesses increasingly evident in the urban space-those perccived zones of public danger and polluting congestion that were designated as dangerous to the promotion of good public health and that were believed to have generated and propagated epidemic or endemic phenomena. ${ }^{13}$ Places commonly termed "filthy" included overcrowded graveyards, congested hospitals and public dispensaries, as well as areas of sewage and waste in the sprawling urban slums and industrial factories. As a result of the growing fear and concern over those things and places deemed disgusting, a new group of state health inspectors and sanitary police were implemented and new languages and techniques of cartographic mapping were invented in order to carefully trace onto the urban terrain the rise of "filth" and its associative diseases. 14 In short, this authoritative growing public health movement functioned as a "regime of health for populations," putting into place the elements of a modern disciplinary regime. 15 Evident throughout the literature associated with sanitary reports was the reasoning that if one could excise filth from urban life, the overall health of the social body would improve.

The decaying dead body became one of the major sources of this acute anxiery and distaste, and specifically the excessive 
number of corpses that were unidentified and unburied in the city centres or in the overcrowded parish churchyards at the end of the eighteenth century. Concerns about public contagion and hygiene mounted as, for example, the piles of cadavers of those who lacked the resources or the social stature to have individual graves were thrown, year after year, into such centrally located Parisian cemeteries as the Cemetery of the Holy Innocents. That particular cemetery absorbed some two million Parisians in an area of 60 by 120 square metres during the seven centuries before its closure in 1780 (it contained roughly three hundred bodies per square metre), and civic hcalth officials and the proponents of private cemeteries began to treat the compacted and composting corpses as especially dangerous. ${ }^{16}$ The public's physical proximity to this pcrceived source of danger was cventually regarded as pathogenic: decomposing flesh needed to be removed. In his 1789 report to the Royal Society of Medicine, the Parisian physician Michel-Augustin Thouret ascribed the closure of the Cemetery of the Holy Innocents to its status as a "public health hazard" following his investigation into its atmosphere. 17 "Putrid exhalations" were also cited as one of the horrors and dangers of dead bodies in Dr. George Walker's important 1839 text entitled Gatherings from Graveyards, Particularly Those in London. ${ }^{18}$ In this compilation Walker focused on the "corrosive exhalations of cadavers" and the problem of offensive smells in relation to enclosed spaces, particularly the smell emanating from decaying human flesh. Increasingly represcnted as a terrorizing sanitation problem, one that supposedly led to the contamination of groundwater, the traditional gravcyard thereby became a new object of scrutiny and regulation: displaced from the space of the church or churchyard and its customary rituals, and onto the agenda of the new programs of public hygiene and their promotion of good public health.

As the state of the health of the population in both England and France progressively became one of the most critical and essential issues in the burgeoning urban environments of the nineteenth century, physicians in particular were encouraged to identify with and promote larger collective control measures aimed at improving the overall hygiene, health, and welfare of the population. Increasingly, physicians not only had the task of teaching individuals the basic rules of hygiene, but also, according to Foucault, "the doctor became the great advisor and expert, if not in the art of governing at least in that of observing, correcting, and improving the social 'body' and maintaining it in a permanent state of health." In this regard, physicians at the turn of the nineteenth century became invested not only with the health of individual patients but also with stratcgic cultural authority in matters pertaining to the sickness and health of the population. Aiding the physician to become one of the crucial instruments of social progress and humanitarianism were the political activities and legislative proposals made by various advocates of public health and social medicine aimed to aid the citizen-patient. Among the activities during this period were those of the Paris Public Health Council. ${ }^{19}$ Reformers' actions were obviously instrumental in the medical profession's aims to formulate its professional identity in direct relationship to the notion that a physically healthy body was the basis of the modern state.

In order to gain further professional legitimacy, physicians embraced the principles and strategies of scientific rationalism. Part of this optimistic embrace entailed performing and publishing their findings based on in-depth anatomical observations of the cadaver. Numerous renowned anatomists and authors emphasized in their publications, teachings, and demonstrations the need for their students and their colleagues to be constantly alert to the slightest visible anomalies found during post-mortem examinations and to become assiduous morbid anatomists. At the beginning of the nineteenth century a momentous emphasis was placed on producing an active approach to anatomy: one that would "excite a spirit of observation" and "lead the attention of the student to fact and experience." 20 Consequently, the cadaver developed into an important site in the effort to institute an anatomical basis for scientific medicinc; it became the means to obscrve the material realities of pathological progress and acquire new knowledge of pathological phenomena. The initial and influential works by Matthew Baillie, published in 1793, and by Xavier Bichat, published in 1800, were fundamental to the emergent medical profession. These treatises emphasized the value of post-mortem analysis and embraced the practice of dissection as a rational inquiry into the body. In his preface to his anatomical treatise, The Morbid Anatomy of Some of the Most Important Parts of the Human Body, Baillie stated that his objective was "to explain more minutely than has hitherto been done, the changes of structures arising from the morbid actions in some of the most important parts of the body," in order for the physician to "be better fitted to detect diseased alterations in the organization of parts which are but little, or not at all known." 21 Xavier Bichat also focused, in depth, on the visual observation of the minute physiological phenomena associated with the configurations of disease that one might find during post-mortem examinations. He encouraged physicians to abandon the grid of symptoms with which he claimed thcy had been concerned since the seventeenth century, and advocated a pathological anatomy that studied the presence of disease in the body rather than on its surfaces. Bichat claimed that only by direct examination of the corpse could a physician be provided with "an objective, real, and at last unquestionable foundation for the description of diseases." 22

Throughout the first half of the nineteenth century it was reasoned that thcse new anatomical techniques of seeing and 


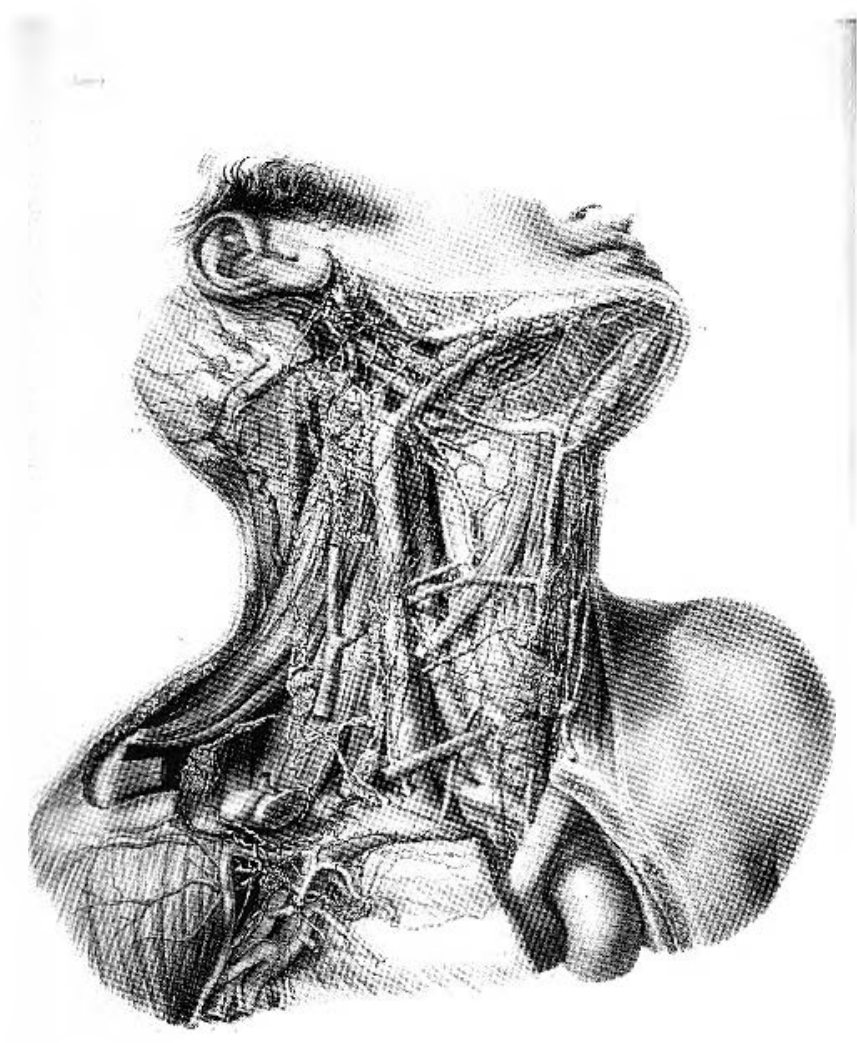

Figure I. Jean Marc Bourgery. Traté Complet de l'Anatomie de l'homme, 1831--54. v. 4. pl. 87. Lithograph by Nicolas Henri Jacob on wove paper. $43.18 \times 30.48 \mathrm{~cm}$. Montreal, Osler Library of the History of Medicine (Photo: Osler Library of the History of Medicine. McGill University).

knowing would not only give concrete form to the professional training physicians had already received, but also that they would establish a new set of "scientific" laws and empirical facts about the body. Consequently, the practising physician and medical student wcre to oppose the outdated "mathematical" forms of knowledge of disease associated with the eightecnth century, and specifically those theories and approaches based on elaborate tables of nosological species and overwhelmingly concerned with specifying and classifying disease. Increasingly, disease was no longer perceived as a pathological species that inserted itself into the body wherever possible and that was linked together by statistically observable concomitances and successions. Rather, disease became something that physicians and medical illustrators claimed was connected to a linear series of morbid events that were observable in the diseased corpse and that could be traced and isolated according to new forms of representation. Duc to this momentous effort placed on anatomiz- ing the cadaver, a syntactical reorganization of disease resulted; new classificatory rules began to dominate medical theory and practice and to appear as the immanent logic of morbid forms. Detailcd guides to dissection were rewritten and new illustrations of the body's interior had to be created. ${ }^{23}$ As this surge in publication of innovative guides and illustrated anatomical atlases occurred, the dead body was no longer considered the site of fear and dread, but became the site of a new, "scientific" technique of codified medical knowledge.

\section{Nineteenth-Century Anatomical Illustration and its Representational Regime}

The nineteenth century was obsessed with visuality and was preoccupied with the role of images and the processes of recognition. Mapmaking and scientific illustration flourished in a host of cultural fields in Western Europe. These new kinds of visual images were frequently used in travel guides, in encyclopedias, and as didactic matcrials in schoolrooms; they soon became a dominant tool of knowledge. ${ }^{24}$ Rooted in the bclief that social truths could be represented visually, they emphasized the visual dimension of generating, disseminating, and using scientific insight. This move to a more visual pedagogy in medical science occurred, significantly, at the same time that the body and its relationship to the discased urban environment were redefined. Pamela Gilbert points out in her study on nineteenth-century medical mapping techniques that as public medicine became fundamental to governing the social body, there was a need for medical and sanitation personnel to conceptualize visual spaces in a way that stressed transparency. Ultimately, these new visual languages were implicated in culcural narratives of social progress that had the goal of achieving a more perfect realization of a population's potential. ${ }^{25}$ In this regard, visual materials must be treated as part of the complex reinforcement of medicine's growing need to establish its professional identity in close relationship to the management of the public sphere.

At the turn of the nineteenth century a large number of physicians and anatomists who performed dissections commented on the need for modern medicine to establish the visual realm as a key epistemological site for their work in the dissection theater. Anatomist Joseph Maclise, for example, maintained in the proface of his 1851 atlas that "illustration by figure is a medium by which this subject may be presented to the understanding in more vivid reality than it can be by any mode of written description." 26 In this regard, the pivotal role of visual communication was seen as enhancing medicine's textual descriptions and taxonomic information, and modern scientific illustrations were increasingly deemed to be more effective than words. As Maclise stated, "An anatomical illustration enters the understanding at once in a direct passage, and 


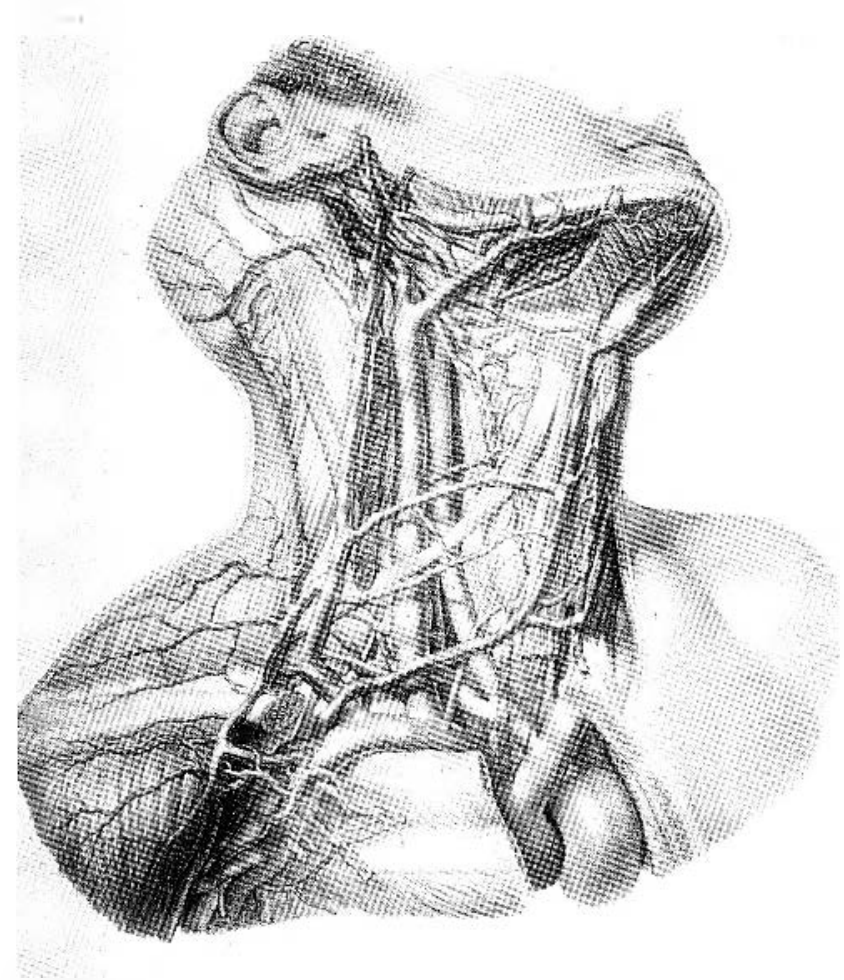

Figure 2. Jean Marc Bourgery. Troité Complet de l'Anatomie de l'homme, 1831-54, v. 4. pl. 67. Lithograph by Nicolas Henri Jacob on wove paper. $43.18 \times 30.48 \mathrm{~cm}$. Montreal, Osler Library of the History of Medicine (Photo: Osler Library of the History of Medicine. McGill University).

is almost independent of the aid of written language. A picture of form is a proposition that solves itself. It is an axiom encompassed in a framework of self-evident truth." 27 According to this broadly held belief, one that can be found echoed in the introductory pages of numerous nineteenth-century anatomical treatises, scientific illustration came to function as "exacting proof" of the anatomist's specialized skills at the dissection table and was based on the notion of a "traincd eye." 28 In this regard, the anatomical atlas came to stand in for the obvious inability of the general public to see that which only a trained professional could clearly understand. In other words, these dissection diagrams came to be viewed as an objective way of seeing that would itself yield knowledge, rather than simply representing knowledge. As a result, the realm of the visible becamc the site wherein physicians actively established transparency for their interventions. Carcfully devised alongside modern techniques of visual reproduction, especially the new and precise methods of lithography and chromo-lithography, ${ }^{29}$ these persuasive images conferred on medicine specialized, epistemological credibility. Used in relation to encyclopedic tables or organized into thick, illustrated medical treatises that relied on images rather than text or tables to convey scientific content, these elaborate plates became important modes for envisioning biological "truth."

French surgcon and anatomist Jean-Marc Bourgery devoted over two decades to completing an cight-volume, illustrated, folio-sized atlas - Traité complet de l'anatomie de l'homme - that laid out the interior of the body according to the ncw anatomical discourse. ${ }^{30}$ A spectacular total of 726 hand-coloured lithographs by Nicolas-Henri Jacob (a student of Jacques-Louis David) were contained in this highly refined atlas that many have considered the most remarkable anatomical work to be published in any languages during the ninetecnth century. As with the illustrations in most other anatomy atlases from this period, the intended function for each of the illustrated pages was to give each carefully observed anatomical structure an exact and defining visual charactcr. Ultimately, the shared aim of the anatomist, artist, and publisher of such medical atlascs was to simulate the processes of anatomical dissection and to produce an accurate and comprehensive two-dimensional field that would render transparent the chaotic human body and the perplexing routes of pathological disease. In Bourgery's atlas the dissection process was carefully made legible to the human eye; the parts of the body wcre pictured in the order in which the surgeon divided them with the knife, such that the sequencing of the pages was designed to represent the layers of tissue and internal organs as they were observed and peeled away during dissection (figs. 1, 2). Although Bourgery conducted numerous dissections and made countless meticulous observations based on both original and anatomical preparations, the amount of material required for the composition of his atlas forced him to collaborate with others, including anatomical demonstrators working at the Faculty of Medicine of the University of Paris.

Bourgery's atlas also demonstrates clearly the new theoretical belief that whole systcms, rather than just individual organs, could be affected by disease. It is clearly based and rooted in "topographical" anatomical methods that emphasized the relations between various structurcs within specific regions, 31 opposed to "descriptive" anatomical methods that focused solely on describing individual parts. As Michel Foucault has argued, this modern medical gaze did not mercly look at the surface of the body, but claimed to penetrate it, to reveal the hidden seats of disease. 32 The new mode of envisioning the body based on picturing the ordering principles of anatomical dissection was perceived by Bourgery as being necessary in order for medicine and surgery to "take on a more rational form." As he stated in the introduction to his atlas, "All the discoveries in 


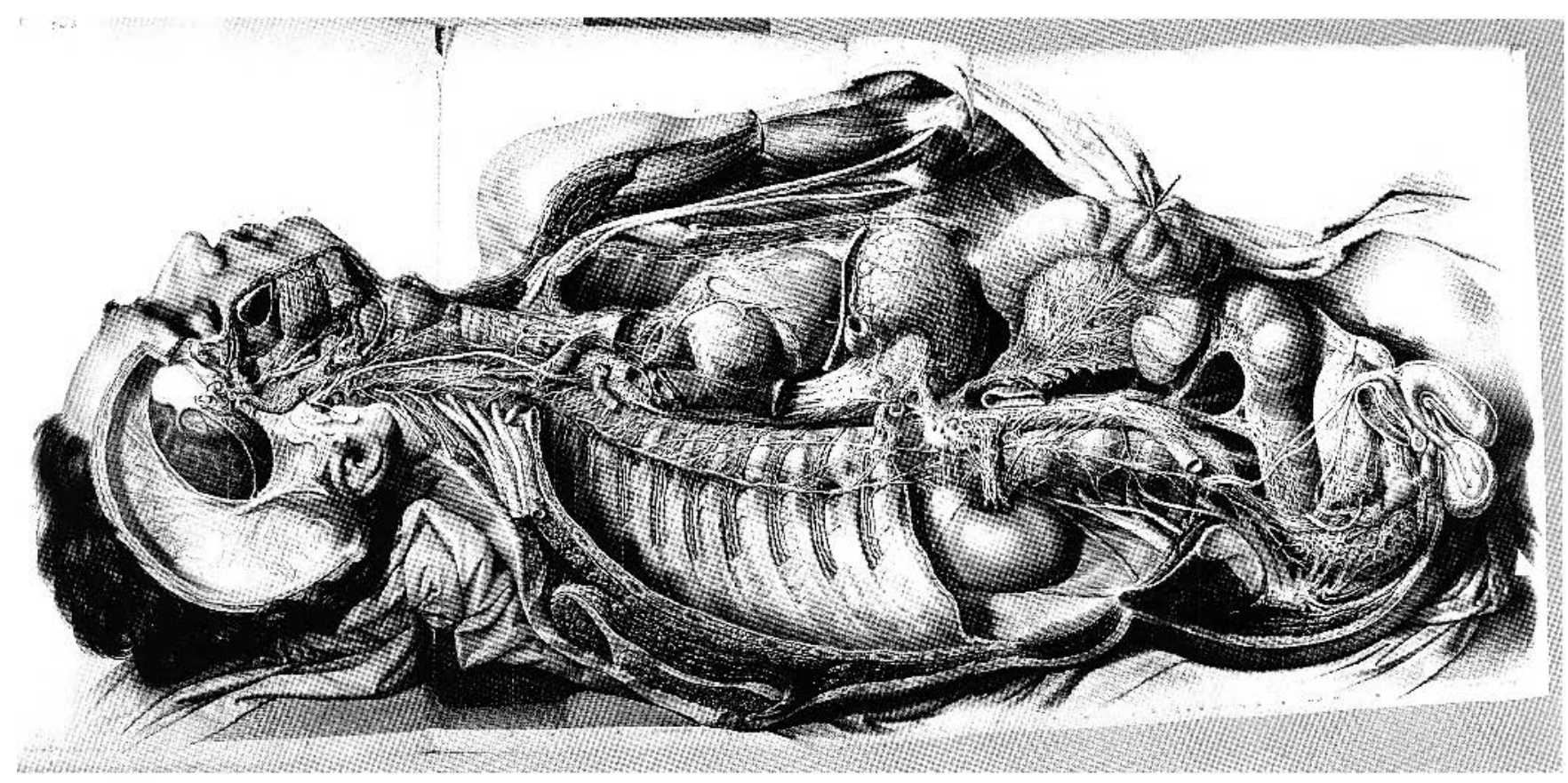

Figure 3. Jean Marc Bourgery. Traité Complet de l'Anatomie de l'homme, 1831-54, v. 3. pl. 100. Foldout lithograph by Nicolas Henri Jacob on wove paper, $43.18 \times 97.79 \mathrm{~cm}$. Montreal, Osler Library of the History of Medicine (Photo: Osler Library of the History of Medicine. Mc Gill University).

the science will have anatomy for its base, all the inventors will be anatomists." 33

As part of the effort to make anatomical atlases act as thorough introductions to the specific principles and practices of topographical ways of seeing and knowing, the atlascs were frequently produced during this period on oversize folio paper. Physicians proudly announced that their use of oversize pages resulted in anatomical images represented on a mathematical scale of $1: 1$ in correspondence with the human body. ${ }^{34}$ As one anatomist claimed, these images were represented "on as large a scale as the sizc of the plates would possibly permit, in order to embrace all the points of reference." 35 The creation of illustrations that wcre the same size as the territory they represented implied that the atlas would be the territory itself. Patrick Joyce argues in his work on nineteenth-century triangulation mapping techniques that as the standardization of space was brought into strict alignment with the belief in mathcmatical perfection, the creation of the illusion of a rational, and therefore governable sense of space was believed to be possiblc. 36 Obviously, medical science quickly and easily drew on the success of these emergent cartographic techniques in order to support its own disciplinary claims of scientific truth and rigour.

The production of Bourgery's atlas also drove a number of important innovations in bookbinding and in illustration techniqucs. In addition to being elaborately bound in full-leather bindings with ornate gold tooling and marbled end papers, the atlas's incorporation of anatomical fold-outs printed on woven paper marked a striking incorporation into the world of the rarc book of what were then the most modern reproductive techniques. A total of eight double-pagc, six triple-page, and two four-page fold-outs were included in Bourgery's multi-volumcd atlas. These meticulously rendered fold-ours werc to be unfolded vertically or horizontally in order to reveal one spatially legible and conceptually coherent imagc. A spectacular four-shect folio illustration (fig. 3) inserted at the back of volume three of Bourgery's atlas discloses one elongated and exhaustively detailed image that protrudes well beyond the covers of the atlas to measure a remarkable 98 centimetres. Here, minute anatomical details and intra-organic pathways that had for centuries been considered invisible are meticulously presented in a "life-sized" figure from the tip of the head to below the hips. This and related illustrations allowed one's gaze to linger longer over an ever-expanding, yet fully realizable territory in order to follow entire regions of physiological phenomena and data. Jean Cruveilhier, anatomy professor at the Faculty of Medicine at the University of Paris and the first occupant of the Chair of Pathological Anatomy at the Paris Academy (1836), believed that the goal of the anatomist and of his illustrator was to characterize the "substance of organs and their component tissues." 37 In his well-respected altas Cruveilhier noted that the principles of anatomical investigations and illustration should bc based upon reducing the tissues to simple elements, which could then be 


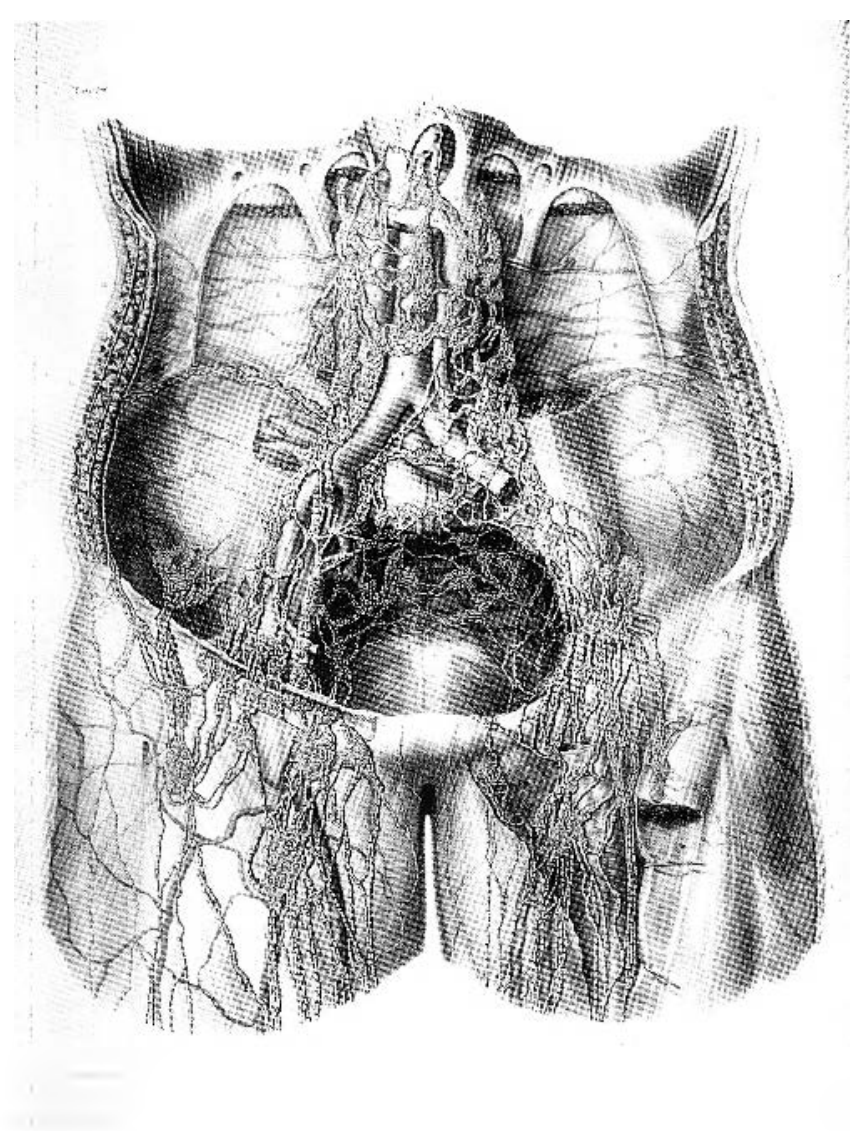

Figure 4. Jean Marc Bourgery. Traité Complet de l'Anatomie de l'homme. 1831-54, v. 4. pl. 89. Lithograph by Nicolas Henri Jacob on wove paper, $43.18 \times 30.48 \mathrm{~cm}$. Montreal, Osler Library of the History of Medicine (Photo: Osler Library of the History of Medicine. McGill University).

combined into various components in order for "the organization of even the most complicated and dissimilar parts to be made manifest." 38

In physically opening, unfolding, and closing these large fold-outs, the observer takes on the subjective position similar to that of the physician's becoming what Foucault has called the "speaking eye." 39) This modern regime of vision hinged upon the observer trying to link extensive lists of captions and anatomical descriptions to a highly coded visual image, rather than mcrely correlating huge volumes of texts with extensive descriptions and case histories, as was the case in nosological medicinc. For example, in Bourgery's multi-volume atlas the new "scientific" reader needed to link the sets of numbers referring to physiological matter, and listed on one page, to tiny numbers that were either discretely hidden in the illustration's myriad details or that were dotted along the perimeter of the illustration on

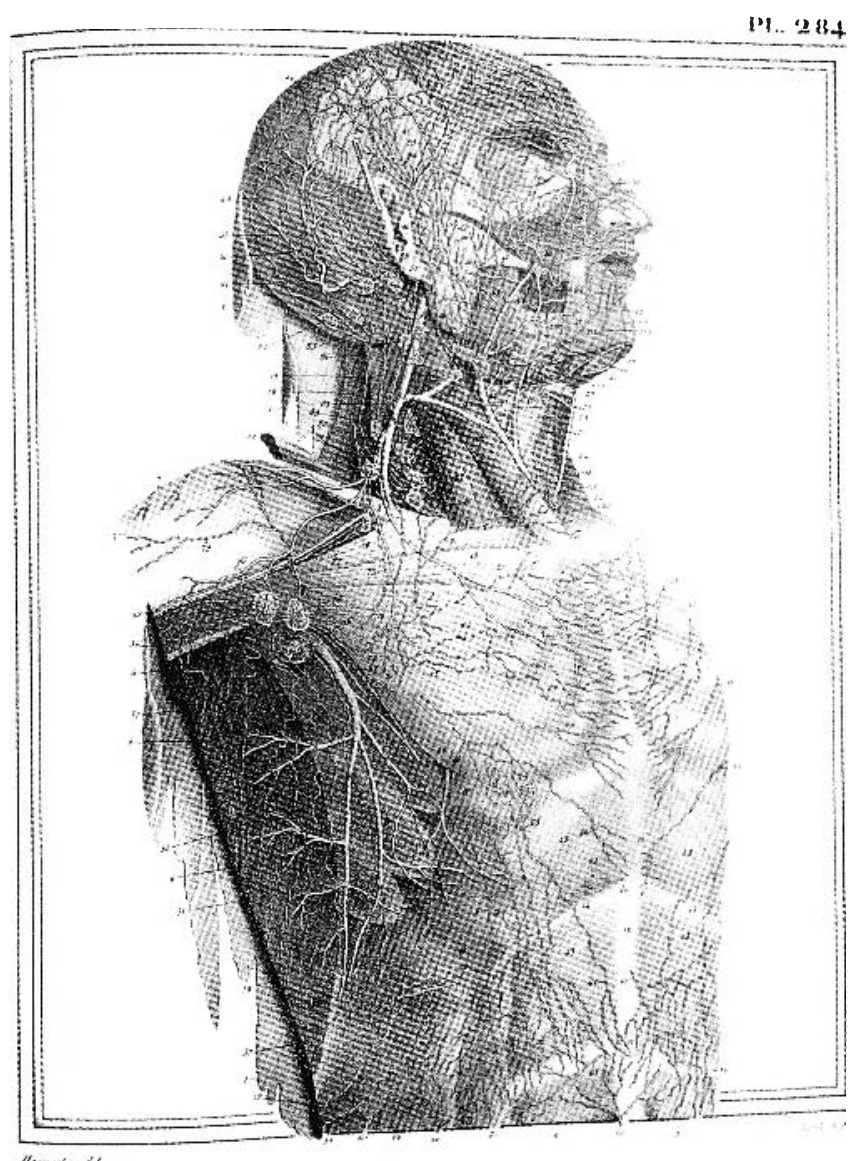

Figure 5. Jules Cloquet, Manuel d'anatomie descriptive du corps humain. representée en planches lithographiées, 1825, v. 2. pl. 284. Lithograph on paper, $25.4 \times 20.32 \mathrm{~cm}$. Montreal, Osler Library of the History of Medicine (Photo: Osler Library of the History of Medicine, McGill University).

the opposite pagc. 40 Other atlases, such as Jules Cloquet's threeand five-volume altases, entailed a viewing/reading process that was much more complex, involving huge amounts of both textual and visual information presented in at least two volumes (each of which consisted of anatomical descriptions as well as extensive numerical and alphabetical codes), and a separate illustrated volume.

In obviously painstaking efforts to translate into standardized visual form what only decades before had been believed to be below the threshold of visibility, the nineteenth-century anatomical atlas could claim to have discovered and visualized new physiological recesses and mechanisms. The "discovery" at this time of the lymphatic system, for instance, had a notable effect on the approach to illustration, which began to focus on portraying the chains of lymph nodes as they extended across the entire body (figs. 4,5$)$. Defined by one notable anatomist in his 


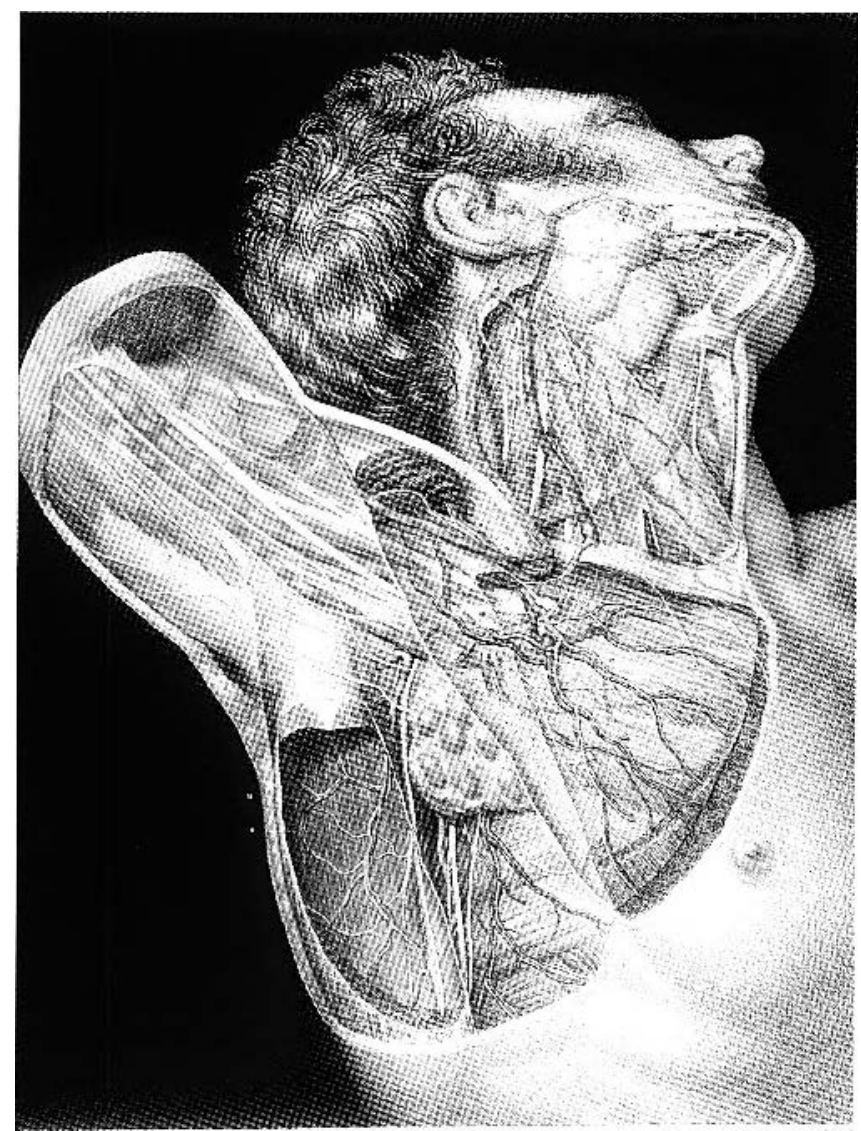

Figure 6. Jean Marc Bourgery, Troité Complet de l'Anotomie de l'homme, 1831-54. v. 4, pl. 6. Lithograph by Nicolas Henri Jacob on wove paper $43.18 \times 30.48 \mathrm{~cm}$. Montreal, Osler Library of the History of Medicine (Photo: Osler Library of the History of Medicıne, McGill University).

1831 atlas as "vesscls which subdivide to infinity in its substance or at its surfaces," 41 delicately webbed lymphatic tissues were frequently represented as delicate lacework atop muscle, bone, and organs. Importance was also placed on identifying how whole systems opcrated and how disease transversed, bound together, enveloped, and divided the organs. In this rcgard, these atlases did not promote an improvement on established Galenic anatomical models that localized disease solely within the body's organs, arteries, and veins. Rather, the nineteenth-century atlases reflected an approach that attempted to ensemble a general, yet minute plan of pathological anatomy. Thus, while Bichat encouraged physicians to abandon the grid of symptoms with which they had been concerned since the seventcenth century and to focus in depth on the visual observation of the minute physiological phenomena associated with the configurations of disease that one might find during post-mortem examinations, disease itself became something that physicians and medical illustrators claimed was connected to a linear series of morbid events: a series that could be traced and isolated by new strategies of representations.

What is at stake here is the productive role the atlases performed in constructing nineteenth-century medicine's epistemological claims and specific languages. The anatomical atlas marked a reorganization of the way in which the course of pathology was conceptualized and offered new ways to spatialize the body as new classificatory rules began to dominate medical theory and practice. ${ }^{42}$ Designed to represent what one anatomist described as the "inextricable interlacement of disease," 43 these illustrated treatises created a new language and landscape for human anatomy based on the syntactical reorganization of disease. Nervous systems, sensory organs, vascular routes, and fibrous envelopes and tissues were given a solid and traceable visible form, establishing a specific technical and visual grammar of the supposedly immanent logic of morbid forms. This meant that popular medical subjects, such as the inflammation of serous membranes, that had been a source of confusion for surgeons for dccades, could now be identified by their defining visual characteristics and explained in relation to complex observable networks. Since visualization was assigned a fundamental role in the reform of medical training and education, these images functioned as new forms of visual pedagogy that offered a lucid guide for physicians to cite in explaining, for the first time, the course of specific diseases and in predicting their outcomes.

Yet, although anatomical atlases were based on the desire to elucidate a structure that claimed to be both visible and legible, spatial and recognizable, at the same time, they remained permeated with contradiction. In this regard the illustrations reflected an unremitting degree of both manipulation and reanimation. For instance, in order to accommodate emerging physiological theories based upon deep dissection, the medical mannequin was frequently displayed in foreshortened positions, including being cut off and carved up in bizarre configurations (figs. 6, 7). In many of the plates large sections of the manncquin's anatomy were erased, enhanced, or reattached. The result is an odd type of realism, in the reading of which we are not meant to question the distortions or to question how these large images of dissected body parts are in fact misrepresentations.

Another set of illustrative strategies that attempt to embed the notion of the real involved picturing the medical mannequin in such a way that it appeared, strangely perhaps, as if it were alive. In most atlases an obliging medical mannequin appears to offer himself up as a willing participant in the spectacle of medical science. Although this idea of a "living" anatomical figure was a familiar trope throughout the histories of Western European anatomical illustrations, the artists of the nineteenth- 


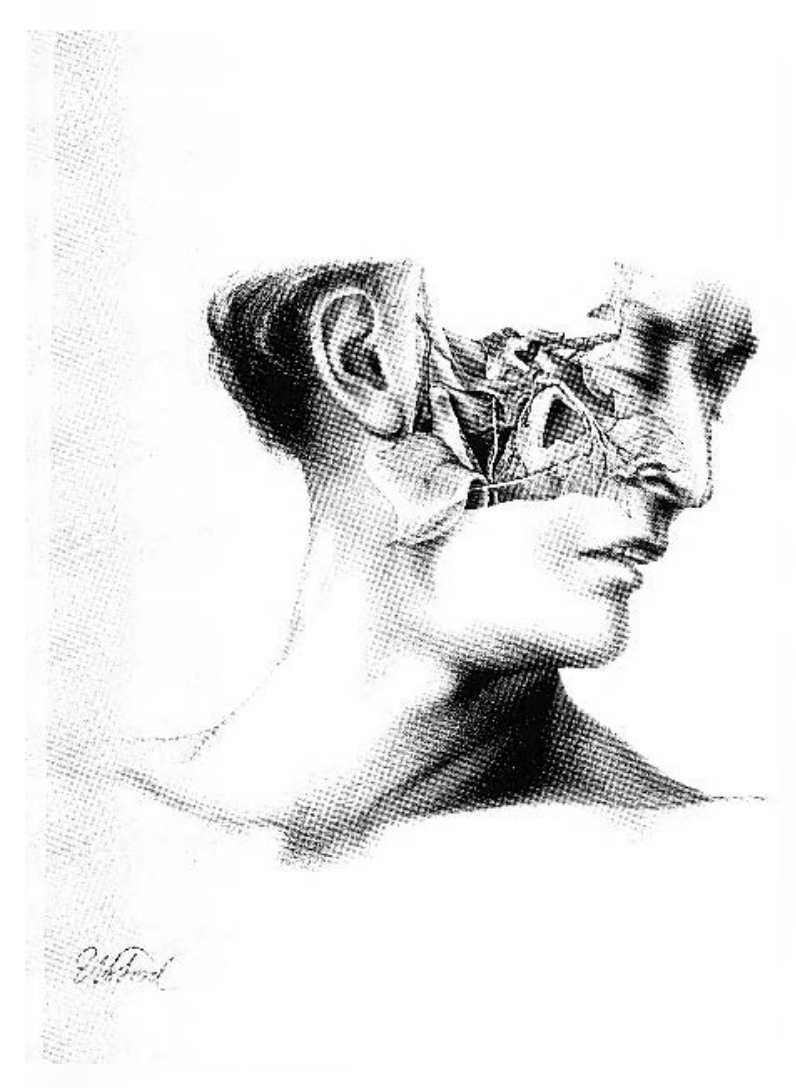

Figure 7. George Viner Ellis. Illustrations of disseclions in a series of original coloured plates, the size of life, representing the dissection of the human body. 1867, v. 2. pl. XXIII. Chromo-lithograph by G.H. Ford on paper, $47 \times 31$ $\mathrm{cm}$. Montreal. Osler Library of the History of Medicine (Photo: Osler Library of the History of Medicine. McGill University).

ccntury anatomical atlas tended to embcllish this effect by making their male mannequins emulate the heroic poses derived from renowned neoclassical art. The figures in the atlases tend to be portrayed at the height of their youth and openly draw upon established academic schools of painting and sculpture rooted in the canon of "the Beautiful and the Perfect." 44 In the introductions to their atlases, illustrators and anatomists frequently praised Greek sculptors and the Italian classical schools as key models for overcoming the challenge of reproducing anatomical "exactness"; they maintained that these key historical archetypes portrayed "the truc relation of anatomy to art." 45 Seemingly caught between the prestige and authority of an imaginary past and the urgency of the new, the heroic "living" figures dis- played warm and healthy skin tones, tensed muscles, and finely combed hair rather than evidence of putrefaction, rigidity, or death. Furthermore, with their eyes consciously diverted from ours, thesc idealized neoclassical models strike poses and gestures that allow viewers to have unobstructed views into the most cavernous reaches of the human body. Auspiciously, onc is invited to see without fear of punishment-seemingly given permission from the medical mannequin to look as long and as intensely as one likes. Encoded to be not quite dead and not quite alive, these "perfect" and obliging figures appear to hover between "life" and the scientific logic associated with anatomical dismemberment.

The focused attempts to present anatomical findings as "natural" clearly meant depicting anatomic elements as if they wcre endowed with a life of thcir own. In most illustrations not only does the mannequin appear animated, but also the anatomical parts show no signs of decay. Rather, the tissues are depicted as vitally alive and thriving. In another odd twist, tissue samples frequently appear to lean toward the viewer as if they possessed animate qualitics. These odd signs of life and movement attempt to unify the elements of the composition. Furthermore, there are no signs of fat on these idealized bodies. Nor do blood or bodily fluids seem to be present. Clearly, these disagreeable and distasteful bodily aspects and their abject associations were too unappealing-too messy, pcrhaps. The cutapart bodies float in the air, free of all contexts and cleansed of their association with death. Atlas illustrations thereby allowed the reader the opportunity to become immersed in a picturesque field of vicw-to wander and explore the intricacies of disease and to marvel at its apparent beauty, instead of being repclled or horrified by the topics of morbidity and death. Thus, while the visual rhetoric of the anatomical atlas was bound up with the historical development of realist codes of scientific illustration, it was also beholden to an ideal. In the medical illustrations the question of the visible is a twisted one; while the unruly order of disease was made the object of systematic and critical surveillance, it was simultaneously enlivened with ornamentation, exoticism, and intrigue. The visual imagery of the pathologi$\mathrm{cal}$ atlas succeeded at mastering certain realist representational techniques and strategies, while simultaneously engaging the aesthetic and curious sensibilities of the reader.

\section{Conclusion}

The relation between knowledge and bodies can never be reduced to a smooth relation between sceing and representation-a notion that was, and often still is, upheld in the field of medical illustration. Rather, the visualization of anatomy must be treated as an extraordinarily complex envisioning process. This essay has focused on how nincteenth-century medical illus- 
trations not only became a critical part of the professionalization of modern medicine, but also were an instrumentalizing part of a larger administrative, institutional, and representational struggle involving the regulation and visualization of the social body. It has examined the ways in which the medical community at the beginning of the nineteenth century in Western Europe was motivated by particular cultural, political, and public health concerns to present its findings in specific forms of representation for which it could claim transparency and truth. Bascd upon observations of a large number of dissected corpses, these new forms of anatomical representation treated the interior of the body as if it were an ever-expanding, yet fully realizable territory. For these reasons, nineteenth-century anatomical illustrations became an important site in the production of new forms of power and scientific truth.

Anatomical atlases operated as privileged scientific procedures, as powerful teaching procedures and tools, and as innovative forms of visual communication that spatialized the practices of medical discourse. Clinical medicine's "objective" ways of seeing and knowing were cxtended to precise visual representations. As a result, the realm of the visible became instrumental to scientific medicine's authority throughout the nineteenth century-it became the site wherein physicians could readily stake claims for themselves as experts in a kind of knowledge that had increasing claims to importance in the public sphcre. As the anatomical atlases werc cmbedded within the discursive practices and spaces that regulated medical knowledge and scientific authority, they gave form to the conflicts and contradictions associated with the nineteenth-century project of scientific truth. It was, after all, the goal of the modern and scientific physician to turn the disease-infested body into a vision of modern health that reformers idealized and desired.

\section{Notes}

1 See K.B. Roberts and J.D. Tomlinson, The Fabric of the Body: Furopean Traditions of Anatomical Illustration (Oxford, 1992); and Roy Porter, The Cambridge Illustrated History of Medicine (Oxford, 2001).

2 A few examplcs of major museum exhibitions that have highlighted anatomical imagery in the past decade include: Martin Kemp and Marina Wallace, Spectacular Bodies: The Art and Science of the Human Body from Leonardo to Now (Los Angcles, 2000); The New York Public Library, Seeing is Believing: 700 Years of Scientific and Medical Illustration (New York, 1999); and Mimi Cazort, Ingenious Machine of Nature: Four Centuries of Art and Anatomy (Ottawa, 1996).

3 Sarah Walker Schroth, The Physician's Art: Representations of Art and Medicine (Norch Carolina, 1999), foreword.

4 William MacKcnzie, An Appeal to the Public and to the Legislature on the Necessity of Affording Dead Bodies to the Schools of Anatomy by Legislative Enactment (London, 1824).

5 MacKenzie, An Appeal to the Public and to the Legislature, 4.

6 MacKenzie, An Appeal to the Public and to the Legislature, 15.

MacKenzie, An Appeal to the Public and to the Legislature, 11-12.

8 For a detailed analysis of the social and political circumstances and consequences of the Anatomy Act, see Ruth Richardson, Death, Dissection and the Destitute (London, 1987).

9 The literature dealing with nineteenth-century medicine's practical, institutional, and scientific histories has been cxtensive. Sec Michel Foucault, The Birth of the Clinic: An Archaeology of Medical Perception, trans. A.M. Sheridan Smith (London, 1973); W.F. Bynum, Science and the Practice of Medicine in the Nineteenth Century (Cambridge, 1994); John Lesch, Science and Medicine in France: The Emergence of Experimental Physiology, 1790-1855 (Cambridge, 1984); and Russell Maulitz, Morbid Appearances: The Anatomy of Pathology in the Early Nineteenth Century (New York, 1987). For an analysis of the existing historiography of the Paris Clinical School, see (aroline Hannaway and Ann F. La Berge, eds., Constructing Paris Medicine. Clio Medica 50 (Wellcome Institute Series in the History of Medicinc, 1998).

10 In the 1830s and the 1840s there were three massive waves of contagious disease in london and Paris: the first, from 1831 to 1833 , included two influcnza epidemics and the initial appearance of cholera; the second, from 1836 to 1842, encompassed epidemics of influenza, typhus, typhoid, and cholera; the third, in 1849, was the worst outbreak of cholera, especially for London. See Catherine J. Kudlick, Cholera in Post-Revolutionary Paris: A Cultural History (California, 1996); and Petcr Baldwin, Contagion and the State in Europe, 1830-1930 (Cambridge, 1999).

11 Sce J.N. Hays, The Burdens of Disease: Epidemics and Human Response in Western History (New Jcrscy, 1998), esp. chapters 7-10; and Bruce Haley, The Healthy Body and Victorian Culture (Cambridge, Mass., 1978).

12 For an analysis of the British transition from late eighteenth- to early nineteenth-century perspectives, sce John Pickstone, "Dearth, Dirt and Fever Epidemics: Rewriting the History of British 'Public Healch', 1780-1850," in Epidemics and Ideas, ed. 'lerence Ranger and Paul Slack (Cambridge, U.K, 1992), 125-48; and Christopher Hamlin, Public Health and Social Justice in the Age of Chadwick: Britain, 1800-1854 (Cambridgc, U.K., 1998). For an analysis of French public health methodologics and reform initiatives, scc Ann La Berge, Mission and Method: The Early Nineteenth-Century French Public Health Movement (Cambridge, U.K., 1992).

13 For a summary of the perceived sources of miasma and a listing of nuisances in Britain as they were gathered together from local and national health reports, see W. and R. Chambers, Sanitary Economy: its principles and practice: and its moral influence on the progress of civilization (London, 1850). For a summary of French medical incuiries into the propagation of disease, see Fclix Pascalis, $A n$ 
Exposition of the Dangers of Interment in (ities (Ncw York, 1823).

14 On nineteenth-century medical maps and cultural thcories of space, sec lamela Cilberr, Mapping the Victorian Social Body (AIbany, 2004). For an examination of the concepts of filth in the nineteenth century, see William A. Cohen and Ryan Johnson, cds., Filth: Dirt, Disgust, and Modern life (Minneapolis, 2005). Cohen maintains that "filth represents a cultural location at which the human body, social hicrarchy, psychological subjectivity, and material objects converge" (p. viii).

15 My argument here is indebted to Foucault's work on the emcrgence of social medicine in Western Europe and how the programs of hygiene functioncd as a new network of power that was aimed at the "social body" and inscribed in the broader field of the health of populations. Foucault explains that as a uniquely modern assemblage of powcr associated with the rise of a liberal democratic modc of governance emerged, power began to be exercised "within the social body, rather than from above it." See Michel Foucault, "Governmentality," Ideology and Consciousness 6 (1986): 5-21; rcprinted in The Foucault Effect: Studies in Governmentality, ed. (iraham Burchell, Colin Gordon, and Peter Miller (Chicago, 1991), 87-104. See also Foucault, "The Birth of Biopolitics," "The Birth of Social Medicinc," and "The Politics of Health in the Eighteenth Century," all reprinted in The Essential Foucault: Selections from Fssential Works of Foucault, 1954-1984, ed. Paul Rabinow and Nikolas Rose (New York, 2003), 202-07; 319-37; 338-50.

16 Sec Thomas Lacquer's examination of hygenics and the overpopulation of corpses at the Cemetery of the Holy Innocents in "Spaces of the Dead in Modernity," Cultural Matters 2 (Fall 2001).

17 Michel-Augustin Thouret, Rapport sur les exhumations du cimetière et de l'Église des Saints-Innocents, lu dans la séance de la Sociète royale de médecine tenue au Louvre le 3 mars 1789 (Paris, 1789).

18 George Walker, Gatherings from (iraveyards, Particularly Those of London with a Concise History of the Modes of Interment Among Different Nations From the Earliest Periods and a Detail of Dangerous of Fatal Results Produced by the Unwise \& Revolting Custom of Inhumi (London, 1839).

19) Refer to Dora Weiner, The Citizen-Patient in Revolutionary and Imperial Paris (Baltimore and London, 1993).

20 See Matchew Baille, The Morbid Anatomy of Some of the Most Important Parts of the Human Body (London, 1793).

21 Baille, The Morbid Anatomy of Some of the Most Important Parts of the Human Body.

22 Xavier Bichar, Traité des membranes en général et de diverses membranes en particulier (Paris, 1799).

2.3 See John Shaw, A Manual of Anatomy: Containing Rules for Displaying the Structure of the Body, so as to Exhibit the Elementary Views of Anatomy, and Their Application to Pathology and Surgery; to which are Added, Observations on the Art of Making Anatomical Preparations (London, 1822). It is a prime example of the new guides that demonstrate the ncw classification rules that governed the disscc- tion of the corpsc. Another popular dissection guide was James Scratchley's The London Dissector; or System of Dissection Practiced in the Hospitals and Lecture Rooms of the Metropolis; Explained by the Clearest Rules, For the (Ise of Siudents: Comprising a Description of the Muscles, Vessels, Nerves, and Viscera, of the Human Body, as They Appear on Dissection; with Directions for their Demonstration (London, 1811).

24 Sec Patricia Anderson, The Printed Image and the Transformation of Popular Culture, 1790-1860) (0xford, 1991). See also Pamcla Gilbert on the increased visibility of maps from 1830 to 1855 (the "golden agc" of thematic mapping) in Mapping the Victorian Social $B o d y$. For an analysis of nincteenth-century scientific visual culturc and its relationship to visual pleasure, see Annc Secord, "Botany on a Plate: Pleasure and the Power of Pictures in Promoting Early Nineteenth-Century Scicntific Knowledge," Isis 93 (2002): 28-57.

25 Gilbcrt, Mapping the Victorian Social Body.

26 Joseph Maclise, Surgical Anatomy (London: 1851), preface.

27 Maclise, Surgical Anatomy, prefacc.

28 For examplc, Friedrich Ticdmann noted in the introduction of his atlas that he worked on his publication for sixtcen years and that he had dissected approximately five hundred bodies. See Friedrich Tiedcmann, Plates of the Arteries of the Human Body (Edinburgh, 1835). Similarily, Samuel Wilks, in the preface of his treatise stared: "It seems right to say, as a mere matter of fact, that I have for the last fifteen years made a daily study of the disscction of the dead, that I have now for many years held the appointment of Demonstrator of Morbid Anatomy, and that I have myself recorded between 2000 and 3000 inspections, of which we have an average at (iuy's Hospital of more than 250 annually." Scc Samucl Wilks, Lectures on Pathological Anatomy (London, 1859).

29) Lithography was introduced into France and England around 1801 and chromo-lithography was developed in 1837. The atlases marked a striking incorporation of what were then the most modern reproductive techniqucs. For a history of lithography, see Geoffrey Ashall (ilaister, Encyclopedia of the Book (London, 1996).

30 Jean Marc Bourgery, Traité complet de l'anatomie de l'homme (Paris, 18.31-1854.)

31 The original sourcc for this theory is Bichat, Traite des membranes en général et de diverses membranes en particulier.

32 Foucault, The Birth of the Clinic, csp. his section on the medical gaze, 107-22.

33 Bourgery, Iraité complet de l'anatomie de l'homme, Tome 1, preface.

34 George Viner Ellis, Illustrations of Dissections in a Series of Original Coloured Plates, the Size of Life, Representing the Dissection of the Human Body (London, 1867).

35 John Lizars, A System of Anatomical Plates of the Human Body, Accompanied with Descriptions and Physiological, Pathological, and Surgical Observations (Edinburgh, 1822-26).

36 Patrick Joyce examines social mapping techniques and develops the important link between statistics and mapping as it rclates to a 
liberal form of government in The Rule of Freedom: Liberalism and the Modern City (London, 2003), esp. chapter 1.

37 See Jean Cruveilhier, Anatomie pathologique du corps humain: ou, Descriptions, avec figures lithographiées et coloriées, des diverses altérations morbides dont le corps humain est susceptible (Paris, 1829-42).

38 Cruveilhier, Anatomie pathologique du corps humain.

39) Foucault, The Birth of the Clinic, esp. his section on the medical gaze, 107-22.

40 Sce Bourgery, Iraité complet de l'anatomie de l'homme.

41 Robert Knox, A System of Human Anatomy on the Basis of "Traité d'Anatomie Descriptive" of M.H. Cloquet (Edinburgh, 1831), 758.

12 Othmar Keel examines the conceptual and institutional factors that pathology played in the transformation of Western medicinc in the British and French schools in his article "Was Anatomical and Tissue Pathology a Product of the Paris Clinical School of Nor?" in Caroline Hannaway and Ann F. La Berge, eds., Constructing Paris Medicine, Clio Medica 50 (Wellcome Institute Series in the History of Medicine, 1998), 117-83.

43 Knox, A System of Human Anatomy, 758.

44 For more on the theory of "the Beautiful in rclation to the discovery of Nature in art and anatomy," see Julien Fau, Anatomy of the External Forms of Man, Intended for the use of Artists, Painters and Sculptors (London, 1849).

45 On the importance of historic art to anatomical illustrators, sce Cieorge Simpson, The Anatomy of the Bones and Muscles, Exhibiting the Parts as They Appear on Dissection, and More Particularly in the Living Figure; as Applicable to the Fine Arts. Designed for the Use of Artists, and Members of the Artists' Anatomical Society (London, 1825). Another important and popular source that praised the anatomical work of historical artists, such as Lconardo and $\mathrm{Mi}$ chelangelo, was Robert Knox's Great Artists and Great Anatomists: A Biographical and Philosophical Study (London, 1852). 